\title{
Hubungan antara ketuban pecah dini dengan nilai Apgar pada kehamilan aterm
}

\author{
Rico Alexander*, Armon Rahimi, Zulfikri Mukhtar, Djohan, Rudi Chandra, Syamsul Arifin \\ Nasution \\ Fakultas Kedokteran Universitas Prima Indonesia
}

*Korespondensi: rcortho11@gmail.com

DOI: 10.34012/jpms.v3i1.1775

(c) 2021 JPMS. All rights reserved

\begin{abstract}
Abstrak
Ketuban pecah dini merupakan salah satu penyebab terjadinya asfiksia neonatorum dan infeksi yang dapat meningkatkan mortalitas dan morbiditas perinatal. Penelitian ini bertujuan untuk menilai hubungan antara lama ketuban pecah dini dengan nilai Apgar pada kehamilan aterm yang dirawat inap di Rumah Sakit Umum Mitra Sejati Medan. Jenis penelitian yang digunakan adalah penelitian analitik dengan desain penelitian cross sectional dengan metode pengambilan sampel accidental sampling. Dari sampel yang memenuhi kriteria restriksi didapat 68 ibu dengan kasus KPD. Hasil penelitian menunjukkan hasil lama KPD $<12$ jam dengan Apgar baik adalah sebesar 22 kasus $(73,3 \%)$ dan dengan Apgar buruk sebanyak 8 kasus $(26,7 \%)$ sedangkan KPD $\geq 12$ jam dengan Apgar baik sebesar 10 kasus (26,3\%) dan nilai Apgar buruk sebesar 28 kasus (73,7\%). Dari uji statistik dengan tes Chi Square didapatkan nilai $\mathrm{X} 2=14,876$ dan probabilitasnya $(\rho)=0,001$. Dapat disimpulkan terdapat hubungan antara lama ketuban pecah dini dengan nilai Apgar.
\end{abstract}

Kata kunci: ketuban pecah dini, nilai Apgar

\begin{abstract}
Premature rupture of membranes is one of the causes of neonatal asphyxia and infection that can increase the perinatal mortality and morbidity. This study assesses the relationship between the duration of premature rupture of membranes with the Apgar-Score in term pregnancies hospitalized at Mitra Sejati Medan Hospital. The type of research used is analytic research with cross-sectional research design with an accidental sampling method. From the sample that met the restriction criteria, there were 68 mothers with PROM cases. The results showed that the duration of PROM $<12$ hours with good Apgar was 22 cases (73.3\%) and poor Apgar were 8 cases (26.7\%) while PROM 12 hours with good Apgar were 10 cases (26.3\%) and poor Apgar scores of 28 cases (73.7\%). From the statistical test with the Chi-Square test, the value of $X 2=14.876$ and the probability $(\rho)=0.001$. It can be concluded that there is a relationship between the duration of premature rupture of membranes and the ApgarScore.
\end{abstract}

Keywords: premature rupture of membranes, Apgar-Score

\section{Pendahuluan}

Ketuban pecah dini merupakan masalah penting dalam obstetri berkaitan dengan penyulit kelahiran prematur dan terjadinya infeksi sampai sepsis yang meningkatkan morbiditas dan mortalitas perinatal dan menyebabkan infeksi ibu. Hal ini dapat terjadi pada akhir kehamilan maupun jauh sebelum waktunya melahirkan. ${ }^{1}$

Ukuran keberhasilan suatu pelayanan kesehatan tercermin dari penurunan angka kematian ibu (Maternity Mortality Rate) sampai pada batas angka terendah yang dapat dicapai sesuai dengan kondisi dan situasi setempat serta waktu. ${ }^{2}$

Berdasarkan Survei Demografi dan Kesehatan Indonesia (SDKI), Penurunan angka kematian ibu (AKI) di Indonesia terjadi sejak tahun 1991 sampai dengan 2007, yaitu dari 390 menjadi 228 per 100.000 kelahiran hidup (KH). Namun demikian SDKI tahun 2012 menunjukkan peningkatan AKI yang signifikan yaitu mencapai 359 kematian ibu per 100.000 kelahiran hidup. ${ }^{3}$ AKI kembali menunjukkan penurunan menjadi 305 kematian ibu per 100.000 kelahiran hidup, berdasarkan hasil Survei Penduduk Antara Sensus (SUPAS) pada tahun $2015 .^{4}$ 
Lima penyebab langsung kematian ibu terbesar karena akibat langsung dari penyakit penyulit persalinan yaitu: perdarahan, hipertensi dalam kehamilan (HDK), infeksi, partus lama/macet, dan abortus. Sementara itu masih banyak penyebab-penyebab lain yang dapat mempersulit persalinan pada ibu, seperti emboli air ketuban, trauma anestesi, trauma operasi, dan lain-lain. ${ }^{5}$

Ketuban pecah dini merupakan suatu kejadian obstetrik yang banyak ditemukan, dengan insiden sekitar 10,7\% dari seluruh persalinan, di mana $94 \%$ di antaranya terjadi pada kehamilan cukup bulan. Ini terjadi pada sekitar 6-20\% kehamilan. Apabila terjadi sebelum kehamilan aterm maka lebih banyak masalah dari pada terjadi pada kehamilan aterm. Menurut World Health Organization (WHO) angka kejadian ketuban pecah dini pada tahun 2013 sebanyak 50-60\%. Sedangkan di Indonesia pada tahun 2013 sebanyak 35\%.

Ketuban pecah dini disebabkan oleh karena berkurangnya kekuatan membran atau meningkatnya tekanan intrauterin atau oleh kedua faktor tersebut. Berkurangnya kekuatan membran disebabkan oleh adanya infeksi yang dapat berasal dari vagina dan servik. Ketuban pecah dini merupakan salah satu faktor penyebab asfiksia neonatorum dan infeksi. Hipoksia pada janin yang menyebabkan asfiksia neonatorum terjadi karena gangguan pertukaran transport gas $\mathrm{O} 2$ dari ibu ke janin sehingga terdapat gangguan dalam persediaan $\mathrm{O} 2$ dan dalam menghilangkan $\mathrm{CO}$. Gangguan ini dapat berlangsung secara menahun akibat kondisi atau kelainan pada ibu selama kehamilan atau secara mendadak karena hal-hal yang diderita pada ibu dalam persalinan. ${ }^{6}$ Ketuban pecah dini merupakan sumber persalinan prematuritas, infeksi dalam rahim terhadap ibu maupun janin yang cukup besar dan potensiil. Oleh karena itu, tatalaksana ketuban pecah dini memerlukan tindakan yang rinci sehingga dapat menurunkan kejadian persalinan prematuritas dan infeksi dalam rahim. Bila persalinan tertunda sampai 24 jam kemungkinan terjadi infeksi sangat besar.
Fase laten pada ketuban pecah dini merupakan lamanya waktu sejak ketuban pecah sampai terjadi proses persalinan. Semakin panjang fase laten, semakin besar kemungkinan pengaruh terhadap nilai apgar dan akan semakin besar kemungkinan terjadinya infeksi yang berasal dari traktus urogenital bawah. Semakin panjang masa laten juga akan mengakibatkan terjadinya hipoksia hingga fetal distress dan berlanjut menjadi asfiksia neonatorum pada bayi baru lahir. KPD yang memanjang adalah yang terjadi lebih dari 12 jam sebelum waktunya melahirkan, yang mempunyai peranan penting terhadap nilai apgar dan timbulnya infeksi pada bayi yang akan berujung menjadi asfiksia neonatorum. ${ }^{7}$

Penelitian ini menyelidiki hubungan antara lamanya ketuban pecah dini yang mempengaruhi nilai Apgar. Nilai Apgar merupakan salah satu cara untuk menilai kondisi post natal atau bayi yang baru lahir dengan patokan klinis untuk menilai keadaan bayi baru lahir 1,5, dan 10 menit yang meliputi beberapa aspek penilaian yaitu frekuensi jantung (heart rate), usaha bernafas (respiratory effort), tonus otot (muscle tone), refleks terhadap rangsangan (respon to stimuli), warna kulit (colour of skin). ${ }^{6}$

\section{Metode}

Penelitian ini bertujuan untuk menilai hubungan antara lama ketuban pecah dini dengan nilai Apgar pada kehamilan aterm yang dirawat inap di Rumah Sakit Umum Mitra Sejati Medan. Jenis penelitian yang digunakan adalah penelitian analitik dengan desain penelitian cross sectional dengan metode pengambilan sampel accidental sampling. Dari sampel yang memenuhi kriteria restriksi didapat 68 ibu dengan kasus KPD. Kriteria inklusi antara lain ibu hamil dengan KPD, usia kehamilan aterm, ibu hamil yang tidak menderita penyakit kronis dan persalinan berlangsung spontan maupun persalinan dengan tindakan (forcep, vakum, ekstrasi, sestio sesarea).

\section{Hasil}

Pada tabel 1 diketahui bahwa usia ibu 
sebagian besar 20-35 tahun sebanyak 50 orang $(73,5 \%)$ dan sedikit usia $<20$ dan $>35$ tahun hanya 18 orang $(26,5 \%)$. Semua umur kehamilan ibu dalam kategori cukup bulan (aterm) sebesar $100 \%$. Tindakan persalinan responden SC lebih banyak yaitu 39 orang $(57,4 \%)$ sedangkan persalinan normal 29 orang (42,6\%).

Ibu melahirkan dengan kasus KPD memiliki nilai Apgar yang buruk lebih banyak yaitu 36 orang $(52,9 \%)$ sedangkan nilai Apgar yang baik hanya 32 orang $(47,1 \%)$. Sementara itu ibu melahirkan dengan kasus KPD $<12$ jam terdapat 30 orang $(44,1 \%)$ sedangkan kasus KPD $>12$ jam lebih banyak yaitu 38 orang (55,9\%). Timbulnya infeksi pada bayi yang dilahirkan akibat KP lebih banyak yaitu 45 orang $(66,2 \%)$ sedangkan yang tidak menimbulkan infeksi hanya 23 orang (33,8\%) (lihat Tabel 2).

Tabel 1. Karakteristik responden $(n=68)$

\begin{tabular}{lll}
\hline \multicolumn{1}{c}{ Karakteristik } & \multicolumn{2}{c}{ Jumlah } \\
\cline { 2 - 3 } & $\mathbf{n}$ & $\%$ \\
\hline Usia Ibu & 50 & 73,5 \\
$\quad$ 20-35 tahun & 18 & 26,5 \\
$\quad<20$ dan $>35$ tahun & & \\
Umur Kehamilan & 68 & 100 \\
$\quad$ Aterm & & \\
Tindakan Persalinan & 29 & 42,6 \\
$\quad$ Spontan & 39 & 57,4 \\
$\quad$ SC & & \\
Nilai Apgar & 32 & 47,1 \\
$\quad$ Baik (>7) & 36 & 52,9 \\
$\quad$ Buruk (<7) & & \\
Masa Laten KPD selama Proses Melahirkan & 30 & 44,1 \\
$\quad<12$ jam & 38 & 55,9 \\
$\quad>12$ jam & & \\
Timbulnya Infeksi Pada Bayi Selama Melahirkan & 23 & 33,8 \\
$\quad-$ & 45 & 66,2 \\
\hline
\end{tabular}

Tabel 2. Hubungan masa laten ketuban pecah dini dengan nilai Apgar

\begin{tabular}{rccccc}
\hline \multirow{2}{*}{ KPD } & \multicolumn{2}{c}{ Nilai Apgar } & \multirow{2}{*}{ Total } & p & \multirow{2}{*}{ X2 } \\
\cline { 2 - 4 } & Baik & Buruk & & & \\
\hline$<12$ jam & $22(73,3 \%)$ & $8(26,7 \%)$ & $30(100 \%)$ & \multirow{2}{*}{ jo,001 } & \multirow{2}{*}{14,876} \\
\hline 12 jam & $10(26,3 \%)$ & $28(73,7 \%)$ & $38(100 \%)$ & & \\
\hline
\end{tabular}

Tabel 3. Hubungan masa laten ketuban pecah dini dengan timbulnya infeksi pada bayi

\begin{tabular}{rccccc}
\hline \multirow{2}{*}{ KPD } & \multicolumn{2}{c}{ Infeksi } & Total & p & \multirow{2}{*}{$\chi 2$} \\
\cline { 2 - 4 } & - & + & & & \\
\hline$<12$ jam & $23(76,7 \%)$ & $7(23,3 \%)$ & $30(100 \%)$ & $<0,001$ & 44,024 \\
$>12$ jam & - & $38(100 \%)$ & $38(100 \%)$ & & \\
\hline
\end{tabular}

Pada tabel 2 dapat dilihat bahwa dari 30 orang KPD $<12$ jam yang memperoleh nilai
Apgar baik sebanyak 22 orang $(73,3 \%)$ dan nilai Apgar buruk 8 orang $(26,7 \%)$. Sedangkan dari 38 
orang KPD >12 jam yang memperoleh nilai Apgar baik sebanyak 10 orang $(26,3 \%)$ dan nilai Apgar buruk 28 orang $(73,7 \%)$. Hasil uji statistik menunjukkan bahwa ada hubungan yang signifikan antara masa laten ketuban pecah dini dengan nilai Apgar pada kehamilan aterm ( $p=$ $<0,001)$.

Pada tabel 3 dapat dilihat bahwa dari 30 orang KPD $<12$ jam yang menimbulkan infeksi terhadap bayi adalah sebanyak 7 orang $(23,3 \%)$ dan yang tidak terkena infeksi sebanyak 23 orang $(76,7 \%)$. Sedangkan dari 38 orang KPD $>12$ jam yang menimbulkan infeksi adalah keseluruhannya yaitu 38 orang (100\%). Hasil uji statistik menunjukkan bahwa ada hubungan yang signifikan antara masa laten ketuban pecah dini dengan timbulnya infeksi pada kehamilan aterm $(p=<0,001)$.

Tabel 4. Hubungan nilai Apgar terhadap pemilihan tindakan persalinan $(n=29)$

\begin{tabular}{lccccc}
\hline \multirow{2}{*}{ KPD } & \multicolumn{2}{c}{ Nilai Apgar } & \multirow{2}{*}{ Total } & p & \multirow{2}{*}{$\chi 2$} \\
\cline { 2 - 4 } & \multicolumn{2}{c}{ Baik } & Buruk & & \\
\hline Spontan & $8(27,6 \%)$ & $21(72,4 \%)$ & $29(100 \%)$ & \multirow{2}{*}{0,006} & \multirow{2}{*}{7,696} \\
SC & $24(61,5 \%)$ & $15(38,5 \%)$ & $39(100 \%)$ & & \\
\hline
\end{tabular}

Pada tabel 4 dapat dilihat bahwa dari 29 ibu yang memilih tindakan persalinan secara spontan memiliki nilai Apgar baik pada bayi adalah sebanyak 8 orang $(27,6 \%)$ dan bayi yang memiliki nilai Apgar buruk adalah sebanyak 21 orang (72,4\%). Sedangkan dari 39 ibu yang memilih tindakan persalinan SC dengan nilai Apgar baik pada bayi adalah sebanyak 24 orang (61,5\%) dan bayi yang memiliki nilai Apgar buruk adalah sebanyak 15 orang (38,5\%). Hasil uji statistik menunjukkan bahwa ada hubungan yang signifikan antara pemilihan tindakan persalinan dengan nilai Apgar bayi pada kehamilan aterm $(p=0,006)$.

Berdasarkan pengujian dengan korelasi Spearman diperoleh koefisien korelasi $(r)$ antara masa laten KPD dengan timbulnya infeksi $(r)=$ 0,805 artinya hubungan antara keduanya adalah sangat kuat. Uji korelasi antara masa laten KPD dengan nilai Apgar menghasilkan koefisien korelasi $(r)$ sebesar 0,468 yang artinya hubungan antara keduanya adalah sedang. Uji korelasi antara timbulnya infeksi dengan nilai Apgar menghasilkan koefisien korelasi ( $r$ ) sebesar 0,447 yang berarti hubungan antara keduanya adalah sedang. Uji korelasi antara pemilihan tindakan persalinan dengan nilai Apgar menghasilkan koefisien korelasi ( $r$ ) sebesar 0,336 (sedang).

\section{Pembahasan}

Penelitian dilakukan di bagian obstetri ruang bersalin RS Mitra Sejati Medan dengan melibatkan 68 sampel yang melahirkan dengan kasus KPD.

Teori yang berkembang menyimpulkan bahwa rendahnya nilai Apgar (<7) sangat mempengaruhi timbulnya asfiksia pada bayi. Asfiksia adalah suatu keadaan gawat bayi berupa kegagalan bernafas secara spontan dan teratur segera setelah lahir dengan melihat indikator nilai Apgar yang rendah yang dapat mengakibatkan hipoksia, hiperkarbia dan asidemia yang selanjutnya akan meningkatkan pemakaian sumber energi dan mengganggu sirkulasi bayi. Bayi dengan Apgar score rendah pada menit pertama meningkatkan kebutuhan prosedur ventilasi mekanik dan pemasangan kateter umbilikal sehingga meningkatkan terjadi risiko sepsis neonatorum pada bayi-bayi baru lahir. Di Nepal asfiksia menjadi penyebab utama kematian neonatal dini $33,0 \%{ }^{8}$

American Academy of Pediatrics dan American College of Obstetrician and Gynecologyst menetapkan empat kriteria yang harus ada dalam mendefinisikan asfiksia, yaitu: asidosis metabolik atau asidosis campuran dengan $\mathrm{pH}<7,00$ pada arteri umbilikalis, nilai apgar 0-3 pada menit kelima atau lebih, manifestasi neurologi segera pada periode perinatal seperti kejang, hipotonus, koma atau ensefalopati hipoksia iskemi, dan ada bukti 
disfungsi multiorgan pada periode neonatal. ${ }^{9}$

Ketuban pecah dini merupakan masalah penting dalam obstetri berkaitan dengan penyulit kelahiran yaitu meliputi kelahiran kurang bulan, sindrom gawat napas, kompresi tali pusat, khorioamnionitis, abruptio plasenta, sampai kematian janin yang meningkatkan mortalitas dan morbiditas perinatal. Masa laten/lama persalinan yaitu merupakan durasi waktu yang terjadi pada saat proses persalinan berlangsung $>24$ jam. Semakin lama waktu persalinan, maka akan semakin tinggi morbiditas dan mortalitas janin, semakin rendah pula nilai Apgar yang diperoleh oleh bayi dan semakin mudah menimbulkan keadaan asfiksia. Bila persalinan berlangsung lama dapat menimbulkan komplikasi baik terhadap ibu maupun pada bayi dan dapat meningkatkan angka kematian ibu dan bayi. Faktor yang mempengaruhi masa laten selama proses melahirkan adalah his yang tidak efisien, mal presentasi dan mal posisi, janin besar, panggul sempit dan ketuban pecah $\operatorname{dini}(\mathrm{KPD}){ }^{6}$

Pasien yang mengalami ketuban pecah dini 50\%-75\% akan mengalami persalinan secara spontan dalam waktu 48 jam, 33\% akan mengalami sindrom gawat napas, 32\%-76\% mengalami kompresi tali pusat, $13 \%-60 \%$ mengalami khorioamnionitis, $4 \%-12 \%$ mengalami abruption plasenta, dan 1\%-2\% kemungkinan mengalami kematian janin. Semakin lama KPD, semakin besar kemungkinan komplikasi yang terjadi, sehingga meningkatkan risiko asfiksia yang akan meningkatkan mortalitas dan morbiditas perinatal. ${ }^{10}$

Tanda adanya infeksi pada ibu melahirkan adalah bila suhu ibu $>380 \mathrm{C}$, air ketuban yang keruh dan berbau, lekosit darah $>15.000 / \mathrm{mm} 3$. Semakin lama periode laten, maka akan semakin besar kemungkinan terjadi infeksi dalam rahim, persalinan prematuritas dan selanjutnya dapat meningkatkan kejadian kesakitan dan kematian ibu dan bayi atau janin dalam rahim. ${ }^{11}$ Adanya hubungan KPD dengan asfiksia dapat dilihat dari jumlah bayi yang menderita asfiksia berat dari ibu yang mengalami KPD. Kejadian KPD juga dapat memudahkan infeksi ascenden, infeksi ini dapat berupa amnionitis dan korionitis atau gabungan dari keduanya yang disebut dengan korioamnionitis. Selain itu korioamnionitis juga dapat dihubungkan dengan lama pecahnya selaput ketuban, jumlah kali periksa dalam dan pola kuman terutama grup staphylococcus $b$ $2,4,5 \cdot \cdot^{12,13}$

Usia ibu juga sangat berpengaruh terhadap kesiapan ibu selama kehamilan maupun menghadapi persalinan. Usia untuk reproduksi optimal bagi seorang ibu adalah antara umur 20-35 tahun. Di bawah atau di atas usia tersebut akan meningkatkan resiko kehamilan dan persalinan. Usia seseorang sedemikian besarnya akan mempengaruhi sistem reproduksi, karena organ reproduksinya sudah mulai berkurang kemampuannya dan keelastisannya dalam menerima kehamilan. Faktor pemilihan tindakan persalinan memberikan kontribusi yang besar terhadap kejadian asfiksia neonatorum. Hal ini disebabkan oleh karena adanya faktor penyulit dalam persalinan, seperti ketuban pecah dini, partus lama dan jenis persalinan, kelahiran sungsang. ${ }^{14}$ Faktor penyebab terjadinya asfiksia neonatorum karena adanya persalinan dengan tindakan yaitu penggunaan alat pada tindakan fakum ekstraksi dan adanya penggunaan obat bius dalam tindakan sectio caesarea. ${ }^{15}$

Umur kehamilan saat bayi dilahirkan cenderung mempengaruhi kejadian asfiksia setelah bayi lahir, ibu yang melahirkan dengan umur kehamilan yang beresiko lebih berpeluang melahirkan bayi asfiksia dari pada ibu yang umur kehamilannya tidak berisiko. Semakin muda umur kehamilan fungsi organ tubuh semakin kurang sempurna, prognosis juga semakin buruk karena masih belum sempurna seperti sistem pernapasan maka terjadilah asfiksia neonatorum. ${ }^{16}$ Studi menunjukkan solusio plasenta, lilitan tali pusat, simpul tali pusat, paritas, dan BBLR berpengaruh terhadap kejadian asfiksia. ${ }^{17}$

\section{Kesimpulan}

Penelitian ini menyimpulkan faktor yang 
berhubungan dengan kejadian ketuban pecah dini di ruang neonatus RS Mitra Sejati Medan adalah faktor ibu (usia ibu, serviks yang inkompeten, mal presentasi, tekanan intra uterine yang meninggi) dan faktor tindakan persalinan (persalinan spontan dan SC). Diharapkan bagi instansi Rumah Sakit untuk lebih meningkatkan cakupan kualitas ANC standar yang meliputi aspek medis, komunikasi dan motivasi ibu hamil serta rujukan sehingga ibu yang beresiko untuk mengalami Ketuban Pecah Dini (KPD) dapat menjaga kesehatan diri dan kehamilan sehingga bayi yang dilahirkan normal tanpa kendala dan sehat.

\section{Referensi}

1. Sarwono P. Ilmu Kebidanan. Penerbit FKUI. Jakarta. 2008

2. Departemen Kesehatan. Asuhan Persalinan Normal. JNPK-KR. Jakarta. 2014.

3. Badan Perencanaan Pembangunan Nasional. 2012. Laporan Pencapaian Tujuan Pembangunan Milenium di Indonesia 2011. Jakarta. Bappenas.

4. Badan Pusat Statistik. Survei Penduduk Antar Sensus 2015. Jakarta. 2015.

5. Kementerian Kesehatan. Riset Kesehatan Dasar 2013. Badan Penelitian dan Pengembangan Kementerian Kesehatan. 2014

6. Amru S. Rustam Mochtar Sinopsis Obstetri. Edisi ke-3. Jilid 1. EGC. Jakarta. 2015

7. Manoe VM, Amir I. Gangguan Fungsi Multi Organ pada Bayi Asfiksia Berat. Sari Pediatri Vol. 5 No. 2: 72-78. 2003

8. Lauren DA, Jessica DE, Meredith TB. 2012. Rujukan Cepat Kebidanan. EGC. Jakarta. 2012.

9. Alhadar AK, Amir I, Oswari H, Windiastuti

E. Korelasi Nilai APGAR Menit Kelima Kurang dari Tujuh dengan Kadar Transaminase Serum pada Bayi Baru Lahir. Sari Pediatri Vol.12 No.3: 2016

10. Wiradharma, Kardana IM, Dharma AIW. Risiko Asfiksia pada Ketuban Pecah Dini di
RSUP Sanglah. Sari Pediatri Vol.14 No.5: 2016.

11. Fadlun AF. Asuhan Kebidanan Patologis. Editor: Aklia Suslia. Selamba Medika. Jakarta. 2012

12. Suwiyoga S, Budayasa RAA. Peran Korioamnionitis Klinik, Lama Ketuban Pecah, dan Jumlah Periksa Dalam pada Ketuban Pecah Dini Kehamilan Aterm terhadap Insiden Sepsis Neonatorum Dini. Cermin Dunia Kedokteran, 239-241. 2007.

13. Hanif $H$, Syahredi SA, Yani FF. Hubungan antara Lama Ketuban Pecah Dini dengan Skor Apgar Neonatus di RSUP dr. M. Djamil Padang. Jurnal Kesehatan Andalas. Vol.6 No.1: 2017.

14. Kementerian Kesehatan. Buku Saku Pelayanan Kesehatan Ibu di Fasilitas Kesehatan Dasar dan Rujukan. Jakarta. 2013

15. Prawirohardjo S. Buku Pedoman Praktis Pelayanan Kesehatan Maternal dan Neonatal. Yayasan Bina Pustaka. Jakarta. 2008

16. Gilang, Notoatmodjo H, Rakhmawatie MD. Faktor- Faktor Yang Berhubungan Dengan Kejadian Asfiksia Neonatorum Jurnal Kedokteran Muhammadiyah Vol.1 No.2: 2012

17. Lestari RD, Bunga NN, Putri KA. Analisis Faktor Penyebab Kejadian Asfiksia pada Bayi Baru Lahir. Jurnal Ners dan Kebidanan, Vol.6 No.2: 251-262. 2019. 